\title{
Data Analytics Dalam Administrasi Pajak Di Indonesia: Kajian Institutional Arrangement
}

\author{
Agung Darono \\ ${ }^{1}$ Pusdiklat Pajak, Jalan Sakti Raya No. 1 Kemanggisan, Jakarta Barat \\ e-mail: agungdarono@kemenkeu.go.id
}

\begin{abstract}
Abstrak
Tulisan ini menyajikan hasil kajian tentang bagaimana institutional arrangement menjadi bagian yang berjalin-kelindan dalam implementasi data analytics di Direktorat Jenderal Pajak (DJP) sebagai otoritas pajak di Indonesia. Dengan menggunakan metode penelitian studi kasus interpretif, kajian ini menyajikan pemahaman(verstehen) terkait dengan institutional arrangement yang dalam konteks penelitian ini bekerja dalam bentuk: (1) Cetak Biru TIK DJP telah secara eksplisit menyebutkan data analytics sebagai pilar dan aplikasistrategis dalam pengembangan TIK DJP; (2) Tata Kelola TIK DJP menyediakan ruang pengembangan TIK (aplikasi ataupun infrastruktur) dengan pendekatan end-user computing sehingga memungkinkan unit pengguna dapat memenuhi kebutuhan pengembangan TIK-nya secara lebih fleksibel sesuai dengan panduan yang telah ditetapkan; (3) interaksi praktikinformal dengan ketentuan formal yang mengarah kepada terbentuknya situasi praktik formal yang sejalan dengan tata kelola TIK DJP. Studi ini mengajukan usulan kerangka kerja yang diharapkan dapat digunakan untuk memahami bagaimana institutional arrangement berperan dalam implementasi data analytics di lingkungan organisasi pemerintahan secara lebih luas.
\end{abstract}

Kata kunci—analisis, data, institusional, kerangka kerja, pajak

\begin{abstract}
This study set out to investigate how institutional arrangements are intertwinned in the implementation of data analytics at the Directorate General of Taxation (DGT) as the Indonesian tax authority. Using an interpretive case study method, this study found a better understanding (verstehen) related to some institutional arrangements which, in this context, worked in three observable forms. These are: (1) the DGT ICT Blueprint has explicitly mentioned that data analytics is a pillar and strategic-application in the development of ICTs; (2) the DGT ICT governance explicitly provides space for ICT development-i.e. applications or infrastructure, with an end-user computing approach so that ICT user units can fulfill their ICT development needs more flexibly in accordance with guidelines in governance; (3)the interaction between informal practices with formal provisions leads to the formation of IT formal practices that are in line with the DGT's ICT governance. This study proposes a conceptual framework that could be used to better understand how institutional arrangements play a key role in the process of implementing data analytics, particularly within a wider range of government organizations.
\end{abstract}

Keywords—analysis, data, framework, institutional, tax 


\section{PENDAHULUAN}

Direktorat Jenderal Pajak (DJP) selaku otoritas pajak di Indonesia berwenang untuk mengumpulkan bukti dan kemudian berdasarkan bukti tersebut menetapkan pajak bagi wajib pajak yang tidak melaksanakan kewajiban pajak sesuai dengan ketentuan yang berlaku. Salah satu bentuk bukti tersebut adalah data yang disimpan dalam format elektronik (data elektronik). Perkembangan teknologi informasi dan komunikasi (TIK) telah memunculkan disiplin data analytics yang dapat dimanfaatkan oleh otoritas pajak untuk mengolah data elektronik tersebut sehingga dapat digunakan untuk mendukung pengambilan keputusan dalam administrasi pajak. Data analytics diharapkan dapat memperkecil kesenjangan (gap) antara jumlah pajak yang telah dibayarkan dibandingkan dengan jumlah pajak yang seharusnya dibayarkan oleh wajib pajak [1, $2,3,4,5,6]$. Beberapa kajian menunjukkan bahwa kebanyakan otoritas pajak telah mengubah pendekatan mereka antara lain dengan menggunakan kepatuhan pajak kooperatif dan juga pemeriksaan pajak berbasis risiko yang berbasiskan pada keandalan aplikasi data analytics [7, $8,9,10,11]$. Sejalan dengan tren global tersebut, DJP juga telah menjadikan data analytics sebagai salah satu pilar pengembangan TIK dan sekaligus menjadi bagian dari fungsi administrasi pajak secara keseluruhan [12,13,14,15,16].

Implementasi data analytics, sebagaimana yang dilaksanakan oleh DJP tersebut, perlu ditelaah tidak hanya dari sisi teknologinya saja namun juga aspek sosio-organisasionalnya. Salah satu hal yang menarik untuk ditelaah lebih mendalam adalah bagaimana institutional arrangement berjalin-kelindan dalam implementasi data analytics sebagai bentuk implementasi TIK [17,18,19,20]. Adanya istilah "getting the institutions right" menunjukkan pentingnya pemahaman akan aspek institutional arrangement dalam aktivitas ekonomi, bisnis, ataupun administrasi, termasuk pula dalam hal implementasi TIK untuk organisasi $[21,22,23,24,25,26]$. Berkaitan dengan implementasi TIK dalam organisasi, [27] menyatakan bahwa institutional arrangement merupakan integrasi antar berbagai aspek yang meliputi lingkungan sosial, kebijakan, aturan, struktur, ataupun prosedur kerja yang memungkinkan implementasi TIK bekerja sebagai komponen organisasi. Beberapa kajian yang menunjukkan bahwa institutional arrangement berkaitan dengan erat dengan kesuksesan implementasi TIK, baik di lingkungan swasta ataupun pemerintahan. Institutional arrangement perlu mendapatkan perhatian dalam implementasi dan operasi TIK dalam organisasi karena hal ini berkaitan dengan serangkaian aturan yang menghubungkan akan teknologi dengan aktor-organisasi beserta lingkungannya sehingga teknologi yang diimplementasikan dapat berjalan [17, 28,29,30,31].

Penelitian ini dengan menggunakan metode penelitian studi kasus interpretif berupaya untuk menyajikan sebuah pemahaman yang empatik dan mendalam (verstehen) yang berasal sebuah fenomena/situasi organisasional dalam bentuk alamiah (naturalistic)-nya berupa institutional arrangement dalam implementasi data analytics di lingkungan administrasi pajak [32, 33,34,35,36:48,37, 38]. Pemahaman empatik yang demikian ini pada dasarnya diperoleh peneliti melalui interpretasi/penafsiran dengan menggunakan sudut pandang subjek-penelitian (emic) atas fenomena sosial-organisasional yang sedang diteliti [32,39:103, 40].

Rumusan masalah penelitian ini adalah bagaimana institutional arrangement menjadi aspek yang ikut berjalin-kelindan (interwinned) dalam implementasi data analytics untuk kepentingan administrasi perpajakan di Indonesia. Manfaat yang diharapkan dari tulisan ini adalah tersedianya sebuah kerangka konsepsual yang memungkinkan para praktisi, akademisi, dan pengambil kebijakan mendapatkan pemahaman yang mendalam (verstehen) sehingga mempunyai tambahan referensi yang berkaitan dengan implementasi data analytics dalam lingkungan administrasi pajak.

Sistem informasi adalah salah satu bentuk implementasi TIK sebagai komponen organisasi yang dibuat agar dapat menyajikan informasi yang valid untuk mendukung pengambilan keputusan. Berdasarkan perlakuannya terhadap jenis data yang disimpannya, sistem informasi dalam organisasi dapat dibedakan menjadi dua yaitu pengolahan transaksi

Darono, [Data Analytics Dalam Administrasi Pajak Di Indonesia: Kajian Institutional Arrangement] 
(transaction processing, sering disebut dengan On Line Transaction Processing/OLTP) ataupun proses analisis (analytical processing, dikenal pula dengan On Line Analytical Processing/OLAP [41,42]. OLTP sering disebut juga sebagai core application adalah sistem aplikasi untuk mengotomasikan pekerjaan klerikal, rutin, terstruktur, berulang, dan merupakan transaksi yang atomik dan terisolasi. Pada sisi lain, OLAP merupakan sebuah sistem aplikasi untuk menyimpan data detil ataupun agregat dengan multidimensional-view dengan menggunakan data yang berasal dari OLTP atau sumber data lainnya untuk menyediakan akses informasi yang cepat bagi kepentingan penggunanya $[43,44,45,46]$.

Istilah OLAP tersebut kemudian memiliki cukup banyak varian yang sebenarnya bertujuan sama namun mempunyai penekanan fungsi yang agak berbeda, sebut saja misalnya: Decision Support Systems (DSS), data mining, data warehouse, ataupun business intelligence. Area praktik analisis data ini yang kemudian diberi istilah sebagai data analytics [47, 48,49,50]. Menurut [47], analytics berbeda dengan analysis, adanya akhiran "-ics" tersebut menunjukkan adanya kerangka atau prinsip-prinsip tentang pengetahuan (body of knowledge), sedangkan "analysis" dapat dimaknai sebagai serangkaian aktivitas. Sementara itu, [51] menyatakan data analytics sebagai proses berbantuan sistem aplikasi dan perangkat lunak untuk menelaah sekumpulan data sehingga darinya bisa didapatkan kesimpulan yang berkaitan pengambilan keputusan bisnis.

Dalam konteks administrasi pajak, [5:16-20] mengajukan istilah advanced analytics untuk mewakili predictive analytics dan prescriptive analytics sebagai bentuk pemrosesan dan analisis data untuk kepentingan administrasi pajak. Menurut [52], predictive analytics merupakan upaya untuk menemukan hubungan antar data perpajakan untuk tujuan antisipatif, sedangkan prescriptive analytics lebih merupakan upaya untuk mencari hubungan sebab-akibat yang dapat diungkapkan dari berbagai data perpajakan yang sudah dikumpulkan. Sementara itu menurut [7], penerapan advanced analytics seperti anomaly detection, predictive modeling dan social network analysis akan mendukung otoritas pajak untuk menemukan indikasi kemungkinan ketidakpatuhan wajib pajak. Sedangkan [2] mengemukakan bahwa penggunaan predictive analytics dalam administrasi pajak dapat menghasilkan pemilihan kasus pemeriksaan pajak yang lebih tepat sasaran.Teknis analisis datanya dapat berupa pattern recognition, outlier detection, cluster analysis, experimental design, network analysis, dan juga text mining. Dari sisi area implementasi praktisnya dalam administrasi pajak dapat mencakup kepentingan yang berkaitan dengan pemilihan wajib pajak yang diaudit, pembayaran dan pelaporan, pengelolaan piutang pajak, layanan perpajakan, segmentasi wajib pajak berdasarkan kriteria tertentu, dan evaluasi kebijakan.

Ketentuan formal tentang pelaksanaan sistem perpajakan di Indonesia telah diatur dalam UU Nomor 6 Tahun 1983 tentang Ketentuan Umum dan Tata Cara Perpajakan beserta Perubahannya (selanjutnya "UU KUP"). Salah satu hal yang diatur dalam UU KUP adalah aliran informasi untuk kepentingan administrasi pajak. Aliran informasi dalam sistem administrasi pajak ini berasal dari dua sumber utama, yaitu wajib pajak sendiri dan pihak ketiga sebagai data pembanding. Kedua aliran informasi tersebut akan menjadi bahan bukti yang dapat diolah oleh DJP sehingga pada akhirnya dapat digunakan menjadi bukti untuk menguji kepatuhan wajib pajak. Data terpenting yang berasal dari wajib pajak berupa Surat Pemberitahuan (SPT) sebagai surat yang digunakan untuk melaporkan penghitungan dan/atau pembayaran pajak, objek pajak dan/atau bukan objek pajak, dan/atau harta dan kewajiban (Pasal 1 angka 11 UU KUP). Sementara itu, data dari pihak ketiga ini, sebagaimana disebutkan dalam Pasal 35A, adalah data yang dapat menggambarkan kegiatan atau usaha, peredaran usaha, penghasilan dan/atau kekayaan yang bersangkutan, termasuk informasi mengenai nasabah debitur, transaksi keuangan, lalu lintas devisa, kartu kredit, serta laporan keuangan dan/atau laporan kegiatan usaha yang disampaikan kepada instansi lain di luar DJP.

Pasal 12 UU KUP menetapkan bahwa jika terdapat bukti yang menunjukkan jumlah pajak 
yang terutang menurut Surat Pemberitahuan (SPT) wajib pajak tidak benar maka DJP menetapkan jumlah pajak yang seharusnya terutang. Sebagai konsekuensi dari ketentuan ini, Pasal 35A UU KUP telah memberikan wewenang kepada DJP untuk mengumpulkan dan mengolah data (termasuk data elektronik) untuk kemudian dapat digunakan menjadi bukti untuk menguji kepatuhan wajib pajak. Berdasarkan ketentuan tersebut, dan juga adanya perkembangan teknologi manajemen data yang telah mengarah pada penggunaan big data oleh otoritas perpajakan (lihat misalnya [53, 54]) maka DJP dapat mengimplementasikan data analytics sebagai salah satu mekanisme untuk mengumpulkan data/informasi untuk kemudian diolah dan disajikan sebagai bukti untuk menguji kepatuhan wajib pajak.

Institutional arrangement merupakan salah satu bagian dari tata kelola TIK (IT governance) yang dapat digunakan untuk memastikan bahwa implementasi TIK telah selaras dengan strategi bisnis organisasi secara keseluruhan. Penyelarasan tersebut berfokus pada perencanaan dan implementasi suatu kerangka kerja sehingga tersedia media komunikasi yang memadai antara fungsi TIK dengan fungsi bisnis organisasi lainnya [18, 55,56, 57,58, 59]. Hasil studi [17] menemukan bukti bahwa institutional arrangement merupakan salah satu prasyarat kesuksesan implementasi big data analytic di sektor pemerintahan. Institutional arrangement tersebut mencakup: (1) institusi formal, termasuk kebijakan, struktur tata kelola dan aturan hukum; (2) berbagai perilaku atau eksternalitas (dampak) yang berkaitan keberadaan data analytics. Kajian OECD [5:31-34] menemukan beberapa hal bahwa implementasi advanced analytics di lingkungan administrasi pajak membutuhkan keselarasan kondisi struktural dan kultural sehingga fungsi yang bersifat teknis dapat bekerja efektif dengan berbagai komponen organisasi lain dalam skala yang lebih luas.

Berdasarkan kajian literatur yang telah dilakukan di atas, penulis mengajukan definisi operasional institutional arrangement yang digunakan penelitian ini, beserta alur pemikiran yang menggambarkan hubungan antara berbagai konsep terkait dengan implementasi data analytics dalam administrasi pajak.Gambar 1 menyajikan diagram alur pemikiran yang menggambarkan hubungan antara konsep, definisi operasional, dan tujuan penelitian.

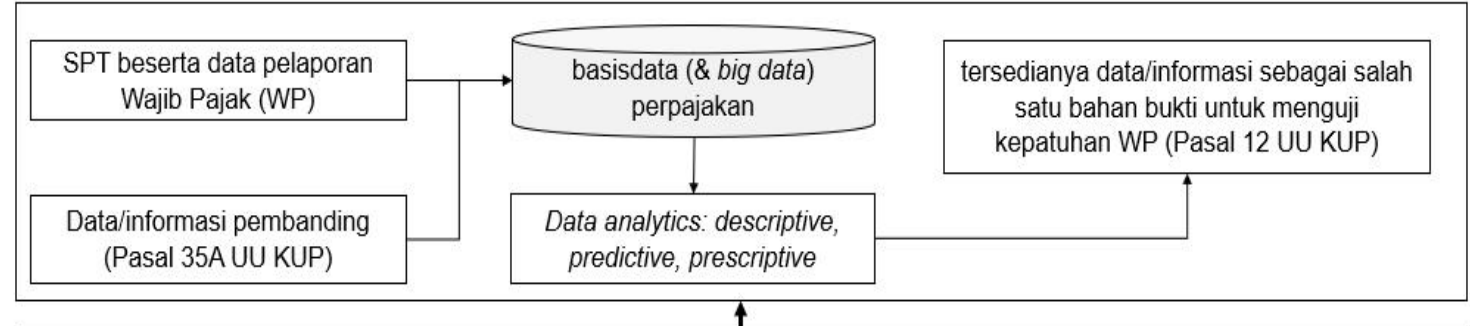

Tujuan penelitian: pemahaman yang mendalam (verstehen) tentang bagaimana institutional arrangement menjadi aspek yang ikut berjalin-kelindan (intertwinned) dalam implementasi data analytics untuk kepentingan administrasi perpajakan di Indonesia

Definisi operasional: institutional arrangement tatanan organisasi yang memungkinkan aktor-organisasi melakukan serangkaian aktivitas untuk mencapai tujuan organisasi dengan merujuk kepada ketentuan formal (seperti: ketentuan hukum, prosedur operasi standar, atau hirarki kewenangan) ataupun situasi non-formal (seperti: nilai-nilai, adat/budaya, atau praktik keseharian organisasi yang wajar) sehingga ia melaksanakan berbagai aktivitas tersebut organisasi (dalam konteks ini adalah implementasi data analytics dalam administrasi pajak) dengan risiko dan biaya transaksi yang minimal.

Gambar 1. Alur Pemikiran dan Definisi Operasional

\section{METODE PENELITIAN}

Penelitian ini menggunakan metode studi kasus interpretif karena metode inidianggap paling sesuai dengan tujuan penelitian untuk mengungkapan situasi empiris untuk mendalami makna yang tersimpan dari situasi sosial-organisasional berupa institutional arrangement yang terkait dengan implementasi data analytics untuk kepentingan administrasi pajak sebagai fokus 
penelitian[36:45,35]. Studi kasus interpretif artinya pemahaman akan suatu kasus akan didapatkan melalui pengungkapan makna dari berbagai data yang dikumpulkan untuk selanjutnya ditafsirkan dengan menggunakan teori/literatur, penelitian terdahulu, dan pengalaman peneliti dengan menggunakan perspektif emic (sudut pandang aktor-organisasi sebagai subjek-penelitian) sehingga didapatkan pemahaman yang mendalam [36:56,34].

Teknik analisis dan interpretasi data yang digunakan adalah analisis tematik (thematic analysis) [60,58] dan disertai dengan protokol triangulasi [61,62] untuk menjaga validitas temuan penelitian. Karena penelitian ini menggunakan strategi penelitian studi kasus interpretif, pemanfaatan hasil penelitian ini kepada lingkungan dan situasi organisasi yang berbeda hendaknya dilakukan dengan mempertimbangkan prinsip-prinsip: transferability, generalisasianalitis, ataupun konteks spesifik yang terkait dengan suatu organisasi [36:73-77, 63,64].

Gambar 2 menyajikan hubungan antara rumusan masalah dengan teknik analisis dan interpretasi data penelitian sebagaimana yang telah diuraikan.

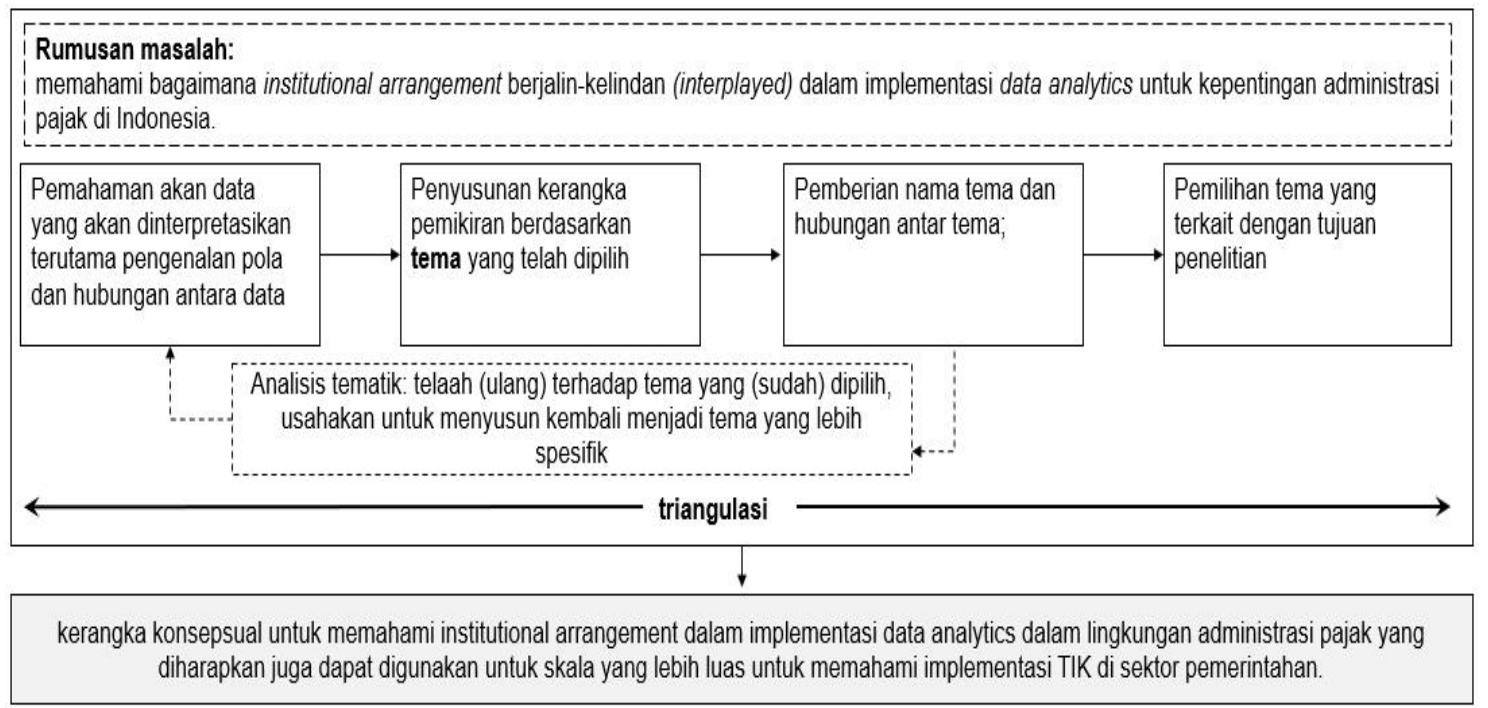

Gambar 2. Teknik Analisis dan Interpretasi Data Penelitian

Penelitian ini menggunakan wawancara (langsung dan via aplikasi Whatsapp) serta studi dokumentasi sebagai cara pengumpulan datanya. Dokumentasi tersebut mencakup antara lain: struktur organisasi, diagram alur proses bisnis, prosedur operasi standar (Standard Operating Procedures/SOP), ataupun materi sosialisasi/seminar yang terkait dengan implementasi data analytics. Tabel 1 menyajikan daftar narasumber (informan) penelitian yang diwawancarai. Panduan umum pertanyaan yang akan diajukan telah disusun dalam protokol studi kasus sebagai panduan bagi penulis dalam melakukan wawancara. Kerangka ini sifatnya fleksibel, artinya dapat disesuaikan dengan situasi dan kondisi pada saat wawancara berlangsung. Penulis diberi kesempatan oleh Direktur Tranformasi Teknologi Komunikasi dan Informasi (TTKI)-DJP untuk melakukan pengumpulan data menggunakan teknik wawancara dengan dua orang staf terkait yaitu NS-1 dan NS-2. Pada saat wawancara dengan NS-1 dan NS-2 terdapat beberapa hal yang menurut penulis perlu mendapatkan pendalaman dengan melakukan wawancara dengan staf TIK di DJP yang terkait dengan implementasi data analytics di instansi vertikal DJP. Untuk kepentingan ini, penulis kemudian mewawancarai informan NS-3 s.d. NS-8. 
Tabel 1. Narasumber Penelitian yang Diwawancarai

\begin{tabular}{ll}
\hline \multicolumn{1}{c}{ Jabatan/Kedudukan } & Identifikasi \\
\hline Kepala Subdirektorat terkait pengembangan sistem informasi dan tata kelola TIK DJP di & NS-1 \\
Direktorat TTKI & \\
Kepala Seksi terkait data analytics dan data warehouse di Direktorat TTKI & NS-2 \\
Kepala Bidang terkait pengelolaan data di Kantor Wilayah & NS-3 \\
Kepala Seksi terkait pengelolaan data di Kantor Wilayah DJP Wajib Pajak Besar & NS-4 \\
Administrator TIK di Kantor Wilayah DJP Wajib Pajak Besar & NS-5 \\
Analisdi Center for Tax Analysis, Direktorat Potensi, Kepatuhan, dan Penerimaan (Dit. & NS-6 \\
$\begin{array}{l}\text { PKP) di Pusdiklat Pajak } \\
\text { Pengolah dan penyaji data di Center for Tax Analysis, Dit. PKP di Pusdiklat Pajak }\end{array}$ & NS-7 \\
$\begin{array}{l}\text { Pemeriksa pajak yang telah mengimplementasikan audit analytics dalam pemeriksaan } \\
\text { pajak yang dilakukannya }\end{array}$ & NS-8 \\
\hline Sumber: pengumpulan data oleh penulis &
\end{tabular}

\section{HASIL DAN PEMBAHASAN}

Pembahasan dilakukan menggunakan kerangka analisis sebagaimana disajikan dalam Gambar 2. Berdasarkan kerangka tersebut, penulis menyajikan hasil analisis dan interpretasi data dalam empat tema yaitu: (1) data analytics di DJP sebagai inisiatif strategis dan situasi terkini yang berkaitan dengan hal itu; (2) implementasi data analytics sebagai bagian dari praktik pengembangan TIK DJP; (3) data governance sebagai bagian dari implementasi data analytics yang perlu mendapatkan telaah lebih mendalam; (4) usulan kerangka kerja yang diajukan memahami institutional arrangement dalam implementasi data analytics.

\subsection{Data Analytics di DJP: Inisiatif dan Situasi Terkini}

Dari sisi arsitekturnya, DJP dapat dibagi menjadi dua bagian besar yaitu infrastruktur dan sistem aplikasi. Dari sisi karakteristik pengolahan datanya, portofolio sistem aplikasi di DJP dapat dikategorikan menjadi (1) sistem informasi layanan wajib pajak; (2) sistem informasi pendukung; (3) sistem informasi utama; (4) sistem pendukung pengambilan keputusan [65]. Dengan menggunakan pendekatan pemetaan sistem aplikasi "McFarlan Strategic Grid", Cetak Biru TIK DJP memosisikan analytics ke dalam kuadran strategic. Sistem aplikasi dalam kuadran strategic artinya adalah aplikasi yang dapat mengubah arah kebijakan dan kegiatan operasional di dalam lingkungan DJP dengan tujuan untuk mengoptimalkan penerimaan pajak. Analytics dikategorikan sebagai aplikasi strategis terutama jika dikaitkan dukungannya untuk pengambilan keputusan baik. Hal ini dapat dilihat dari dari Perdirjen Pajak Nomor PER46/PJ/2015 tentang Cetak Biru TIK DJP yang menekankan pentingnya implementasi big data analytics pilar pengembangan TIK DJP dan analytics sebagai salah satu sistem aplikasi strategis dalam administrasi pajak, sebagaimana kutipan berikut ini:

“...4. Big Data analytics ... Analytics merupakan proses yang tidak terpisahkan dari DJP, khususnya dalam penggalian potensi pajak dan pencegahan penggelapan pajak. ... Big Data analytics bertujuan untuk memperkuat proses analytics yang ... semakin banyak pola dan korelasi yang dapat ditemukan di dalam data perpajakan sehingga keberhasilan proses penggalian potensi pajak dan pencegahan penggelapan pajak pun semakin tinggi." [13:9]

DJP, merujuk [66], menghadapi situasi yang mengharuskan implementasi data analytics karena memang tantangannya nyata, yaitu: (1) jumlah data internal dan eksternal yang dikelola DJP semakin besar; (2) duplicated and scattered database; (3) use case semakin komplek; (4) infrastruktur dan teknologi saat itu tidak dapat menangani data yang besar.Rencana untuk mengimplementasikan data analytics sebagaimana disebutkan dalam Cetak Biru TIK DJP tersebut kemudian dilaksanakan secara bertahap. Berdasarkan data penelitian yang berhasil dikumpulkan, inisiatif implementasi data analytics ini tidak saja terjadi di fungsi TIK DJP 
(Direktorat TTKI) namun juga ditemui setidaknya di dua direktorat lain yaitu Direktorat Potensi, Kepatuhan, dan Penerimaan (Dit. PKP) dan Direktorat Pemeriksaan dan Penagihan (Dit. P2). Sasaran stratregis TIK DJP (TIK 5) adalah peningkatan ketersediaan data dan informasi yang lengkap dan berkualitas hal ini kemudian ditindaklanjuti dalam [13:56] dengan adanya Pengembangan Platform Analytics.

Tabel 2 dengan menggunakan pendekatan kronologis menyajikan linimasa (timeline) terkait dengan berbagai aktivitas organisasi untuk implementasi data analyics tersebut.

Tabel 2. Tahapan Implementasi Data Analytics di DJP

\begin{tabular}{ll}
\hline Kurun waktu & \multicolumn{1}{c}{ Aktivitas yang dilakukan } \\
\hline April 2015 & Cetak Biru TIK DJP (hal. 32) menyatakan bahwa seluruh data history hasil transaksi \\
& yang dimasukkan ke dalam data warehouse. Pembentukan pilot project untuk \\
membangun Enterprise Data Warehouse (EDW). \\
Konfigurasi perangkat untuk pilot project ini adalah: infrastruktur (10 PC i7); total \\
RAM: $160 \mathrm{~GB}$, total core: 40 core; total storage: $10 \mathrm{~TB}$, perangkat lunak pengolah data: \\
Hadoop \\
Use case yang digunakan untuk piloting adalah: \\
(1) analisis Pajak Masukan - Pajak Keluaran; \\
(2) Faktur Pajak Ganda untuk memenuhi kebutuhan akses data oleh CTA dan Kanwil \\
DJP Wajib Pajak Besar.
\end{tabular}

Catatan: use case adalah rangkaian aktivitas dalam satu atau lebih organisasi yang ditunjukkan dengan sebuah diagram (use case diagram), untuk menjelaskan hubungan antara proses bisnis, prosedur, sistem aplikasi dan penggunanya yang jika hal ini dieksekusi akan menghasilkan keluaran tertentu (lihat misalnya: [67], [68, pp. 4-9]).

Januari - Pembangunan EDW sebagai platform teknologi yang mengintegrasikan/ Desember mengkonsolidasikan data dari berbagai sumber internal dan eksternal, mengelola data 2016 dengan memberikan realibilitas dan kepercayaan terhadap data. EDW bertujuan menyediakan "single source of truth" dan akses data yang tercatat.

Konfigurasi perangkat untuk EDW ini adalah:

- cluster Hadoop (data integration): RAM 3,5TB, 504 core, 100 TB storage

- cluster Hadoop (data platform): RAM 4,2 TB, 408 core, 465 TB storage

- cluster EDW: RAM 2 TB, 112 core, 235 TB storage

- perangkat lunak: Hadoop dan Teradata

Februari 2017 Implementasi deep analytics dengan menggunakan beberapa use case, antara lain:

- 2019 - FPTBTS (Faktur Pajak yang Tidak Berdasarkan Transaksi yang Sebenarnya)

- penyediaan data untuk self service business intelligence.

- network analysis untuk fraud transaksi ppn

- social network analysis untuk mendeteksi jaringan distribusi wp, jaringan kepemilikan saham, jaringan hubungan keluarga

- dukungan informasi bagi aplikasi Approweb sebagai untuk menyediakan informasi dalam pelaksanaan proses bisnis inti DJP

Juni 2019 penetapan Peraturan Menteri Keuangan Republik Indonesia Nomor 87/PMK.01/2019 tentang Perubahan atas Peraturan Menteri Keuangan Nomor 217/PMK.01/2018 (PMK87) tentang Organisasi dan Tata Kerja Kementerian Keuangan yang antara lain mengatur pembentukan Direktorat Data dan Informasi Perpajakan (DIP) dengan tugas untuk merumuskan serta melaksanakan kebijakan dan standardisasi teknis di bidang data dan informasi perpajakan.

Beberapa fungsi di dalam DIP yang relevan DIP diskusi tentang data analytics adalah: pengelolaan data internal, pengelolaan data eksternal; analisis data; risiko kepatuhan wajib pajak dan sains data.

Sumber: pengumpulan data oleh penulis 


\subsection{Data Analytics Dalam Praktik Pengembangan TIK DJP}

Pengembangan TIK DJP telah diatur dalam Perdirjen Nomor PER-54/PJ/2010 tentang Kebijakan Pengembangan Teknologi Informasi dan Komunikasi (TIK) Direktorat Jenderal Pajak dan Perubahannya antara lain mengemukakan beberapa ketentuan ini: (1) pengembangan TIK adalah suatu kegiatan untuk membangun, mengubah, atau menyediakan aplikasi dan infrastruktur TIK yang dibutuhkan dalam mendukung operasional di lingkungan DJP; (2) aplikasi adalah suatu sistem berbasis komputer yang ditujukan bagi pengguna atau bagi sistem lain untuk melakukan suatu fungsi tertentu; (3) infrastruktur TIK adalah semua komponen yang terintegrasi yang digunakan untuk mendukung operasional sistem, meliputi perangkat komputer, infrastruktur jaringan, perangkat lunak, basis data, dan perangkat pendukung seperti modem, scanner, printer, dan lain-lain.

Implementasi data analytics, merujuk Tata Kelola TIK DJP, merupakan salah satu bentuk pengembangan TIK yang seharusnya memenuhi kaidah dalam tata kelola tersebut. Hal yang perlu diperhatikan dari Cetak Biru TIK DJP terkait dengan infrastruktur adalah adanya Prinsip Investasi (PI-07) yang menyatakan bahwa pengadaan Barang/Jasa TIK dapat dilakukan oleh unit kerja pengguna dengan spesifikasi teknis yang disetujui oleh Unit Kerja TIK. Sementara itu, ketentuan yang harus diperhatikan dalam Tata Kelola TIK DJP sehubungan dengan aplikasi adalah pengembangannya yang dapat dilakukan dengan cara (1) in-house development: dilakukan secara swakelola oleh Tim Pengembangan Aplikasi dari DJP; (2) outsourced dengan joint development: oleh pihak ketiga melalui suatu perjanjian kerjasama yang didampingi oleh Tim Pendampingan Pengembangan TIK; (3) commercial-off-the-shelf (COTS): dilakukan dengan memanfaatkan aplikasi COTS jika memenuhi minimal $80 \%$ kebutuhan bisnis dan operasional yang ditetapkan; (4) end-user computing (EUC): Unit kerja DJP di luar Direktorat TTKI dapat melakukan pengembangan aplikasi dan/atau pembelian paket software sendiri (dengan ketentuan bahwa aplikasi yang dikembangkan digunakan untuk melakukan pekerjaan yang bersifat analisis (OLAP) dengan tidak mengubah master data yang sudah ada atau menciptakan master data yang baru.

Data analytics sebagai pengembangan TIK DJP tentu melibatkan aplikasi dan infrastruktur. Dari sisi infrastruktur, dalam implementasi data analytics terdapat kemungkinan unit kerja non TIK DJP (unit pengguna/end user) akan melakukan pengadaan infrastruktur (misalnya unit baru atau upgrade perangkat keras komputer) untuk data analytics jika berdasarkan telaah terhadap infrastruktur yang berada dalam cakupan fungsinya dipandang kapasitasnya tidak memadai lagi.

Dari sisi pengembangan aplikasi, praktik data analytics cenderung mendorong pada adanya penerapan EUC. Hal ini sebenarnya juga sejalan dengan Prinsip Umum (PU-06) dalam Cetak Biru TIK DJP menyatakan bahwa kebutuhan EUC diakomodasi dengan batasan bahwa (1) data hasil olahannya tidak disimpan ke dalam basis data core system DJP; (2) tidak digunakan untuk memberikan pelayanan transaksional kepada wajib pajak. Dukungan terhadap pengembangan data analytics dengan EUC ini juga disampaikan oleh beberapa hasil wawancara dengan NS-1, NS-2, NS-5 dan NS6 yang menyatakan bahwa sebaiknya end-user tetap mempunyai hak akses yang memungkinkan mereka mengolah informasi di luar menu standar yang ada karena kebutuhan informasi yang berubah-ubah. Kebutuhan ini akan sulit dipenuhi jika hanya mengandalkan layanan aplikasi yang disediakan oleh fungsi TIK DJP.

Analisis atas data penelitian yang berhasil dikumpulkan dan diolah mengarah pada satu pemahaman bahwa institutional arrangement yang terkait dengan implementasi data analytics sebagai bagian dari praktik pengembangan TIK DJP mengacu kepada Cetak Biru TIK DJP dan Buku IV Tata Kelola TIK DJP adalah:

Unit di luar TTKI (unit pengguna) mempunyai kesempatan untuk melakukan pengembangan TIK dalam bentuk data analytics sesuai dengan kebutuhan, kemampuan, dan perangkat yang dimilikinya;

Aplikasi data analytics lebih baik dikembangkan dengan pendekatan pengembanga

Darono, [Data Analytics Dalam Administrasi Pajak Di Indonesia: Kajian Institutional Arrangement] 
aplikasi EUC karena sifat yang sering ad hoc dan spesifik, nkasus-per-kasus bahkan personal, sebagaimana dinyatakan dalam PU-06, alasan atas hal ini adalah memberikan kesempatan bagi pengguna untuk melakukan improvisasi yang diperlukan untuk mendukung kegiatan operasionalnya. Unit Kerja TIK mengutamakan pengembangan layanan yang bersifat DJP-wide;

Infrastruktur yang digunakan untuk implementasi data analytics, dengan persetujuan Dit. TTKI, dapat diadakan oleh Unit Kerja di luar TTKI sesuai dengan prinsip PI-07;

Catatan terkait dengan ketentuan dalam SE-6/PJ/2011 tentang Pedoman Pengelolaan EUC yang dalam pandangan penulis terlalu rigid dalam penentuan database management system (DBMS) dan perangkat lunak pemrograman. Sebaiknya Dit. TTKI memberikan beberapa alternatif terhadap pemilihan perangkat tersebut, termasuk terkait dengan varian perangkat data analytics yang dapat diimplementasikan oleh unit pengguna.

\subsection{Data Governance Dalam Implementasi Data Analytics}

Implementasi data analytics sebagai salah satu bentuk pengembangan TIK DJP terutama yang dilaksanakan oleh unit kerja di luar TTKI bertujuan untuk mempermudah unit pengguna mendapatkan data yang sesuai dengan tugas dan fungsi. Pada saat yang sama hal itu juga menimbulkan risiko terhadap keamanan data. Narasumber NS-1 dan NS-2 mengemukakan perlunya prosedur dan dukungan teknologi yang menjamin bahwa fleksibilitas pengolahan data tidak akan menganggu keamanan data.

Acuan formal data governance yang dapat digunakan oleh DJP terkait dengan implementasi data analytics ini, dalam hemat penulis adalah Peraturan Presidan Nomor 39 Tahun 2019 tentang Satu Data Indonesia (Perpres-39). Pasal 1 angka 1 Perpres-39 bahwa Satu Data Indonesia adalah kebijakan tata kelola Data pemerintah untuk menghasilkan Data yang akurat, mutakhir, terpadu, dan dapat dipertanggungjawabkan, serta mudah diakses dan dibagi pakaikan antar Instansi Pusat dan Instansi Daerah melalui pemenuhan Standar Data, Metadata, Interoperabilitas Data, dan menggunakan Kode Referensi dan Data Induk. Selain itu, dapat dipertimbangkan kerangka acuan data governance yang diajukan oleh IOTA (2016) terkait dengan "Good Practice Guide Applying Data and Analytics in Tax Administrations". Hasil kajian ini antara lain mengajukan rekomendasi tentang penyusunan data governance, yaitu:

Penggunaan DAMA-DMBOK sebagai data management framework yang selama ini telah diterima secara luas baik di sektor privat maupun publik. Framework ini telah keseluruhan bidang data management yang meliputi: data development, data architecture, data quality, data security, master data, dan meta data management;

Penggunaan data layer architecture yang membagi data yang akan dianalisis dalam beberapa lapisan (layer), di mana setiap layer mempunyai karakteristik dan aturan tersendiri sehingga akan memudahkan penggunaan data sesuai dengan kepentingan pihak yang mengaksesnya.

Pengembangan data governance sebagai bagian dari data management dalam otoritas pajak juga disampaikan oleh [69] dengan mengajukan kerangka "The New Revenue Agency Systems Architecture". Pada prinsipnya kerangka ini merekomendasikan bahwa penyusunan data governance harus memperhatikan adanya karakteristik data yang terdapat dalam system of record, system of engagement dan system of insight. Kerangka ini berangkat dari pendapat bahwa perubahan kedudukan data sebagai bagian dari organisasi perbankan atau keuangan sangat mirip dengan situasi yang terjadi di lingkungan administrasi pajak. Kedudukan data dalam organisasi pada saat ini menjadi berbeda dengan pada saat sebelumnya yang lebih menekankan adanya system of record yaitu sistem pengelolaan data dengan manajemen basis data relasional (RDBMS) yang terstruktur, data bersifat atomik, integritasnya dijaga dengan berbagai constraints, dan relatif lebih mudah dalam pengendalian akses dan penggunaan datanya. Perkembangan selanjutnya adalah munculnya system of engagement yang memunculkan area baru dalam pengelolaan semi-structured data seperti data melalui API,

Darono, [Data Analytics Dalam Administrasi Pajak Di Indonesia: Kajian Institutional Arrangement] 
ataupun dalam format XML atau JSON. Tahap berikutnya adalah berkembanganya system of insight, yaitu data yang berupa data tidak terstruktur, tanpa atribut yang mudah dikenal seperti konten media sosial, data geospasial, e-mail, web blog, click stream dan sejenisnya. Tantanganya yang muncul selanjutnya adalah bagaimana menemukan paduan antara teknologi dan tata kelola yang sesuai dengan karakteristik setiap data yang dikelola suatu organisasi.

Dari sisi pembagian fungsi atau tugas organisasi, data governance terkait dengan data analytics ini seharusnya mengacu pada PMK-87 (lihat kembali Tabel 2) yang sebagaimana dinyatakan dalam Pasal 613 mengatur tugas Subdirektorat Tata Kelola Data dan Informasi untuk melaksanakan penyiapan bahan, penelaahan, penyusunan kebijakan, pemantauan, dan pengendalian perencanaan strategis kebutuhan data dan informasi, kebijakan dan prosedur tata kelola data dan informasi, perancangan arsitektur informasi, dan evaluasi kebijakan teknis operasional mengenai data dan informasi

Pada situasi saat ini, data governance dalam salah satu bagiannya berupa data stewardship (lihat misalnya [69, 70]) sudah ada dan dapat menjadi pijakan awal. Hal ini dapat dilihat dari ketentuan dalam Surat Edaran Dirjen Pajak Nomor: SE-57/PJ/2011 tentang Pedoman Pengelolaan Aset Informasi sebagai ketentuan pelaksanaan dari Perdirjen Nomor PER41/PJ/2010 tentang Kebijakan Pengelolaan Keamanan Informasi DJP. Ketentuan tersebut juga berlaku untuk implementasi data analytics. Ketentuan ini tentunya memerlukan beberapa penyesuaian dengan adanya PMK-87. Pengembangan lebih jauh data governance tidak terbatas pada data analytics, tetapi dalam skala yang lebih luas mencakup juga seluruh data yang dikelola DJP.

Analisis atas data penelitian yang berhasil dikumpulkan dan diolah mengarah pada satu pemahaman bahwa institutional arrangement yang terkait dengan data governance dalam implementasi data analytics sebagai bagian dari praktik pengembangan TIK DJP adalah:

Data governance diharapkan menjadi pranata organisasi yang diharapkan menjadi dari penyeimbang dua kepentingan yang seakan-akan "berlawanan" antara kemudahan akses data di satu sisi, dengan perlindungan keamanan data dan risiko penyalahgunaan data yang merugikan administrasi pajak secara keseluruhan, di sisi yang lain;

Kemungkinan penggunaan Virtual Desktop Infrastructure (VDI) sebagai mekanisme pengolahan data dengan mengunakan virtual machine yang berjalan secara live di data center DJP sehingga data tetap dapat dianalisis tanpa harus menimbulkan risiko yang berdampak pada sisi keamanan dan integritas data;

Surat Edaran Dirjen Pajak Nomor: SE-57/PJ/2011 tentang Pedoman Pengelolaan Aset Informasi sebagai ketentuan pelaksanaan dari Perdirjen Nomor PER-41/PJ/2010 tentang Kebijakan Pengelolaan Keamanan Informasi DJP saat ini merupakan ketentuan yang dapat dikatakan sebagai data governance yang dimiliki oleh DJP pada saat ini, termasuk untuk kepentingan implementasi data analytics dan hal inilah yang memerlukan konsistensi dalam penerapannya.

\subsection{Institutional Arrangement Dalam Implementasi Data Analytics: Suatu Usulan Kerangka Analisis}

Dengan menggunakan prosedur generalisasi-analitis [36:73-74], penulis mengajukan argumentasi bahwa kerangka kerja yang diajukan ini dapat digunakan untuk perangkat analisis untuk memahami implementasi data analytics dalam setting organisasi pemerintahan yang berbeda. Untuk tahap selanjutnya, definisi operasional tentang institutional arrangement perlu ditetapkan. Berdasarkan definisi tersebut tindakan untuk mendapatkan pemahaman dilakukan dengan membandingkan komponen dan dengan yang sudah diidentifikasi pada tahap sebelumnya. Berikutnya, sebagai langkah terakhir adalah mengerucutkan berbagai situasi/fakta organisasi yang dihadapi menjadi tema tertentu untuk dielaborasi lebih lanjut sebagai institutional arrangement yang dianggap berperan dalam implementasi data analytics.

Gambar 3 menyajikan kerangka kerja pemahaman tersebut dan disertai dengan beberapa 
situasi yang terkait dengan pemahaman yang didapatkan. Kerangka pemahaman ini dapat digunakan sebagai basis untuk mengidentifikasi komponen institutional arrangement yang tersedia dan hubungan antar komponen tersebut.

\begin{tabular}{|c|c|c|}
\hline \multicolumn{3}{|c|}{ alur pemikiran, konsep, dan definisi operasional (perhatikan kembali Gambar 1) } \\
\hline \multicolumn{3}{|c|}{ kerangka kerja pemahaman institutional arrangement dalam implementasi data analytics } \\
\hline $\begin{array}{c}\text { pemahaman akan data analytics } \\
\text { sebagai inisiatif strategis dan } \\
\text { operasionalisasinya }\end{array}$ & $\begin{array}{c}\text { Pemahaman akan perlunya } \\
\text { perubahan struktur tata kelola (TIK } \\
\text { dan organisasi) sebagai konsekuensi } \\
\text { implementasi data analytics }\end{array}$ & $\begin{array}{l}\text { Pemahaman tentang bagaimana } \\
\text { interaksi praktik-informal dan } \\
\text { ketentuan formal sebagai bagian } \\
\text { keseluruhan proses implementasi } \\
\text { data analytics }\end{array}$ \\
\hline $\begin{array}{l}\text { - data analytics telah dinyatakan } \\
\text { sebagai bagian dari cetak biru TIK } \\
\text { DJP } \\
\text { - use case terkait dengan beberapa } \\
\text { isu krusial seperti pengungkapan } \\
\text { fraud terkait dengan faktur pajak }\end{array}$ & $\begin{array}{l}\text { - adanya inisiatif pembentukan unit } \\
\text { data analytics/science sebagai dalam } \\
\text { bentuk formal struktur organisasi } \\
\text {-pendekatan end-user-computing } \\
\text { yang dapat digunakan lebih lanjut } \\
\text { untuk data analytics }\end{array}$ & $\begin{array}{l}\text { - praktik data analytic oleh unit CTA } \\
\text { sampai dengan dibentuk DDIP } \\
\text { - praktik data analiytics oleh pemeriksa } \\
\text { pajak dengan beberapa mekanisme } \\
\text { seperti web scraping untuk } \\
\text { mendapatkan data dari core-apps }\end{array}$ \\
\hline
\end{tabular}

Gambar 3. Kerangka Pemahaman Institutional Arrangement Terkait dengan Implementasi Data Analytics Dalam Administrasi Pajak di Indonesia

\section{KESIMPULAN}

Pemahaman akan peranan institutional arrangement yang terkait dengan implementasi data analytics dalam lingkungan administrasi pajak di Indonesia yang ditemukan dari penelitian ini adalah:

Cetak Biru TIK DJP telah secara eksplisit menyebutkan data analytics sebagai pilar dan aplikasi-strategis dalam pengembangan TIK DJP dan kemudian diimplementasikan dengan menggunakan pilot project, pembangunan enterprise datawarehouse, dan implementasi data analytics dengan use case yang diprioritaskan seperti pengungkapan fraud terkait faktur pajak;

Tata Kelola TIK DJP menyediakan ruang pengembangan TIK (aplikasi ataupun infrastruktur) dengan pendekatan end-user computing sehingga unit pengguna TIK dapat memenuhi kebutuhan pengembangan TIK-nya secara lebih fleksibel sesuai dengan panduan dalam tata kelola;

interaksi praktik-informal dan ketentuan formal sebagai bagian keseluruhan proses implementasi data analytics seperti kesadaran akan penting data governance sebagai bagian Tata Kelola TIK yang dapat dikembangkan lebih lanjut menjadi data governance yang lebih komprehensif dengan mempertimbangkan ketentuan formal dan juga best practice yang ditawarkan di area data management ini.

\section{SARAN}

Berdasarkan analisis data dan temuan penelitian sebagaimana yang telah diuraikan sebelumnya, tulisan ini menyampaikan saran sebagai berikut:

Perbaikan pedoman pengembangan EUC terutama yang berkaitan dengan penggunaan perangkat lunak database management system ataupun pemrograman.

Penyusunan data governance yang merujuk kepada ketentuan formal sebagaimana telah diatur dalam Perpres-39 dengan kemungkinan untuk mempertimbangkan panduan data 
management yang dikeluarkan oleh beberapa lembaga kajian ("think tank") bereputasi di bidang ini.

Hasil penelitian ini mengajukan suatu usulan kerangka kerja yang diharapkan dapat digunakan untuk memahami bagaimana institutional arrangement berperan dalam implementasi data analytics untuk kepentingan administrasi pajak.

\section{DAFTAR PUSTAKA}

[1] M. Pijnenburg, W. Kowalczyk, dan Van der H. D. Lissette 2017, "A Roadmap for Analytics in Taxpayer Supervision,” Electron. J. E-Gov., Vol. 15, No. 1, pp. 19-32.

[2] N. Hashimzade, G. Myles, dan M. Rablen 2016, "Predictive Analytics and The Targeting of Audits," J. Econ. Behav. Organ., Vol. 124, No. April, pp. 130-145.

[3] R. Gregg 2015, "Passion for Change and Good Data: The Right Combination for The DATA Act,” J. Gov. Financ. Manag., Vol. 64, No. 2, pp. 48-52.

[4] R.-S. Wua, C. S. Ou, H. Lin, S.-I. Chang, dan D. C. Yen 2012, "Using Data Mining Technique to Enhance Tax Evasion Detection Performance," Expert Syst. Appl., Vol. 2012, No. 39, pp. 8769-8777.

[5] OECD 2016, "Advanced Analytics for Better Tax Administration Putting Data to Work," OECD, Paris.

[6] IOTA 2016, "Applying Data and Analytics in Tax Administration," Intra-European Organisation of Tax Administrations (IOTA).

[7] E. Stankeviciusa dan L. Leonas 2015, "Hybrid Approach Model for Prevention of Tax Evasion and Fraud," Dalam 20th International Scientific Conference Economics and Management - 2015 (ICEM-2015), Kaunas, Lithuania.

[8] J. Martikainen 2012, "Data Mining in Tax Administration - Using Analytics to Enhance Tax Compliance,” Master Thesis, Aalto University School of Business, Helsinki, Finland.

[9] D. Cleary 2011, "Predictive Analytics in the Public Sector: Using Data Mining to Assist Better Target Selection for Audit," Electron. J. E-Gov., Vol. 9, No. 2, pp. 132-140.

[10] Microsoft dan PwC 2017 "Digital Transformation of Tax Administration," Microsoft and Price Waterhouse Coopers Belastingadviseurs N.V., Netherland.

[11] ICAEW 2016, “Data Analytics for External Auditors," International Accounting, Auditing \& Ethics (IAAE).

[12] A. Darono dan Febrian 2019, "Tax Audit Data Analytics using Power BI: a Proof-ofConcept within an Indonesian Case," in Analytics for Management and Economics Conference, HSE University - St Petersburg. 
[13] DJP 2015, “Cetak Biru Teknologi Informasi dan Komunikasi Direktorat Jenderal Pajak Kementerian Keuangan Republik Indonesia Tahun 2015-2019:” Direktorat Jenderal Pajak (DJP)

[14] DJP 2016, “Laporan Tahunan Direktorat Jenderal Pajak 2016,”

[15] DJP 2017, “Laporan Tahunan Direktorat Jenderal Pajak 2017,”

[16] I. Djuniardi 2016, “Next Generation Data Analysis The Implementationof Big Datain Directorate General of Taxes Republic of Indonesia," Dipresentasikan Dalam The 13th ATAIC Annual Technical Conference, Melaka, Malaysia.

[17] L. Tomar, W. Guicheney, H. Kyarisiima, dan T. Zimani 2016, "Big Data in The Public Sector: Selected Applications and Lessons Learned," Inter-American Development Bank.

[18] W. Jho dan K. J. Song 2015, "Institutional and Technological Determinants of Civil eParticipation: Solo or duet?,” Gov. Inf. Q., Vol. 2015, No. 32, pp. 488-495.

[19] R. Kling, H. Rosenbaum, dan S. Sawyer 2005, Understanding and Communicating Social Informatics: A Framework for Studying and Teaching The Human Contexts of Information and Communication Technologies. Medford, New Jersey: Information Today.

[20] W. J. Orlikowski 2000, "Using Technology and Constituting Structures: A Practice Lens for Studying Technology in Organizations,” Organ. Sci., Vol. 11.

[21] B. Haley 2016, "Getting the Institutions Right: Designing the Public Sector to Promote Clean Innovation," Vol. 42, No. S1, pp. S54-S66.

[22] S.-J. Eom, 2010, "The Institutional Dimension of e-Government Promotion: A Comparative Study on Making 'Business Reference Model (BRM)' in the U.S. and Korea," The National Center for Digital Government is supported by The National Science Foundation under, NCDG Working Paper No. 10-001.

[23] C. R. Williamson 2009, "Informal Institutions Rule: Institutional Arrangements and Economic Performance,” Public Choice, Vol. 2009, No. 139, pp. 371-387.

[24] E. T. Meyer 2006, "Socio-Technical Interaction Networks: A Discussion of The Strengths, Weaknessesand Future of Kling's STIN Model," Dalam IFIP International Federation for Information Processing, Volume 223, Social Informatics: An Information Society for All? In Remembrance of Rob Kling, J. Berleur, M. I. Numinen, and J. Impagliazzo, Eds. Boston, MA: Springer, pp. 37-48.

[25] D. C. North 2005, Understanding The Process of Economic Change. Princeton, New Jersey: Princeton University Press.

[26] P. G. Klein 1999, “New Institutional Economics,” The History and Methodology of Law and Economics (Encyclopedia of Law and Economics). Edward Elgar, pp. 456-489. 
[27] S. S. Dawes 2012, "Foreword," in Enacting Electronic Government Success An Integrative Study of Government-wide Websites, Organizational Capabilities, and Institutions, Vol. 31, New York: Springer, pp. vii-viii.

[28] M. A. Avila-Maravilla dan L. F. Luna-Reyes 2018, "Institutional Arrangements in Digital Government Success: The Case of State Government Web Portals in Mexico," Dalam Proceeding ICEGOV'18 Proceedings of the 11th International Conference on Theory and Practice of Electronic Governance, Galway, Ireland, pp. 73-80.

[29] L. F. Luna-Reyes dan J. R. Gil-Garcia 2013, "Understanding The co-Evolution of Institutions, Technology, and Organizations: The Enactment of The State Government Portal of Puebla," p. 10.

[30] J. R. Gil-Garcia 2012, "Towards a Smart State? Inter-agency Collaboration, Information Integration, and Beyond," J. Inf. Polity, Vol. 17, No. 3.

[31] N. K. Hanna, C. Z.- Qiang, K. Kimura, dan S. C. Kuek 2009, "National E-Government Institutions: Functions, Models, and Trends and with Kaoru Kimura and Siou Chew Kuek," Dalam Information and Communications for Development 2009, The World Bank,

[32] B. Yazan 2015, "Three Approaches to Case Study Methods in Education: Yin, Merriam, and Stake," Qual. Rep., vol. 20, no. 2, pp. 134-152.

[33] S. Baskarada 2014, “Qualitative Case Study Guidelines,” Qual. Rep., Vol. 19, No. 40, pp. $1-18$,

[34] M. Keutel dan M. Werner 2011, "Interpretive Case Study Research: Experiences and Recommendations," in MCIS 2011 Proceedings.

[35] R. Piekkari, C. Welch, dan E. Paavilainen 2009, "The Case Study as Disciplinary Convention Evidence From International Business Journals," Organ. Res. Methods, Vol. 12, No. 3, pp. 567-89.

[36] R. K. Yin 2018, Case Study Research and Applications: Design and Methods - Sixth Edition, 6th ed. California: SAGE Publications Ltd.

[37] J. W. Creswell 2013, Research Design: Qualitative, Quantitative, and Mixed Methods Approaches. Thousand Oaks, California: SAGE Publications

[38] L. Oats 2012, “Tax as a Social and Institutional Practice," in Taxation A Fieldwork Research Handbook, L. Oats, Ed, pp. 196-206.

[39] W. L. Neuman 2014, Social Research Methods: Qualitative and Quantitative Approaches, 7th ed. Essex, England: Pearson Education Limited.

[40] D. M. Fetterman 2008, "Emic/Etic Distinction," Encyclopedia of Qualitative Research Methods. SAGE Publications Ltd, p. 249 
[41] N. Ardista, P. Purbandini, dan T. Taufik 2017, "Rancang Bangun Data Warehouse Untuk Pembuatan Laporan dan Analisis pada Data Kunjungan Pasien Rawat Jalan Rumah Sakit Universitas Airlangga Berbasis Online Analytical Processing (OLAP),” J. Inf. Syst. Eng. Bus. Intell., Vol. 3, No. 1, pp. 40-51.

[42] S. D. Purnamasari and A. Wijaya 2017, "Dashboard Sistem Informasi Eksekutif Penjualan,” J. Ilm. MATRIK, Vol. 19, Vo. 3, pp. 207-216.

[43] R. Mukherjee and P. Kar 2017, "A Comparative Review Of Data Warehousing ETL Tools With New Trends and Industry Insight," in 2017 IEEE 7th International Advance Computing Conference, pp. 943-948.

[44] G. Wahyudi 2015, “Implementasi Data Warehouse dan Business Intelligence untuk Pemantauan Penerimaan Pajak Daerah: Studi Kasus pada Dinas Pelayanan Pajak DKI Jakarta,” Tesis Magister, Universitas Indonesia, Jakarta.

[45] M. Kromer and D. Yu 2008, "Adopting BI in an Organization Using Proof-of-Concept Techniques,” Bus. Intell. J., vol. 13, no. 2, pp. 7-12.

[46] S. Chaudhuri and U. Dayal 1997, "An Overview of Data Warehousing and OLAP Technology,” Presented at the ACM Sigmod Record, March 1997.

[47] D. J. Power, C. Heavin, J. McDermott, and M. Daly 2018, "Defining Business Analytics: an Empirical Approach,” J. Bus. Anal., Vol. 1, No. 1, pp. 40-53.

[48] C. Milner and B. Berg, 2017, "Tax Analytics Artificial Intelligence and Machine Learning-Level 5," $\mathrm{PwC}$.

[49] M. Cao, R. Chychyla, and T. Stewart 2015, "Big Data Analytics in Financial Statement Audits," Account. Horiz., Vol. 29, No. 2, pp. 423-429.

[50] L. Duan and Y. Xiong 2015, "Big Data Analytics and Business Analytics," J. Manag. Anal., Vol. 2, No. 1, pp. 1-21.

[51] O. De Bonhom et al 2018, "Data Analytics: The Future of Audit," Instituut van de Bedrijfsrevisoren, Brussel.

[52] A. Veit 2019, "Swimming Upstream: Leveraging Data and Analytics for Taxpayer Engagement - an Australian and International Perspective," EJournal Tax Res., Vol. 16, No. 3, pp. 474-499.

[53] K. A. Houser and D. Sanders 2017, "The Use of Big Data Analytics by The IRS: Efficient Solutions or The End of Privacy as We Know It?," Vanderbilt J. Entertain. Technol. Law, Vol. 19, No. 4, pp. 871-872. 
[54] F. Carina and T. Thompson, "Do IRS Computers Dream About Tax Cheats? Artificial Intelligence and Big Data in Tax Enforcement and Compliance," J. Tax Pract. Proced., no. Feb-Mar, pp. 43-47, 2019.

[55] A. Darono 2018, "Institutional Arrangement in The Implementation of Government's ESB: The Case of Indonesia," in 2018 IEEE 5th International Congress on Information Science and Technology (CiSt), Marrakech, Morocco, pp. 18-23.

[56] D. C. G. Brown and S. Toze 2017, "Information Governance in Digitized Public Administration," Can. Public Adm., Vol. 60, No. 4, pp. 581-604.

[57] W. F. Sorte Junior 2014, "IT Governance in The Brazilian Central Government: Developments and Constraints," Int. J. Technol. Policy Law, Vol. 1, No. 4, p. pp 335349.

[58] P. J. C. Panagiotopoulos 2011, "An Institutional Perspective on Information and Communication Technologies in Governance," Ph.D. Thesis, Department of Information Systems and Computing September - Brunel University, London, UK,

[59] J. E. Fountain 2016, "Building an Enterprise Government: Creating an Ecosystem for Cross-Agency Collaboration in The Next Administration," Partnership for Public Service and IBM Center for Business of Government, Washington, DC.

[60] L. Ayres 2008, “Thematic Coding and Analysis," Encyclopedia of Qualitative Research Methods. pp. 867-868.

[61] R. E. Stake, 2006, Multiple Case Study Analysis, Thousand Oaks, CA: Guilford Press.

[62] M. Raharjo, 2017, "Studi Kasus Dalam Penelitian Kualitatif," Univ. Islam Negeri Maulana Malik Ibrahim Malang, pp. 1-26.

[63] J. A. Maxwell and M. Chmiel 2014, "Generalization in and from Qualitative Analysis," in The SAGE Handbook of Qualitative Data Analysis, U. Flicks, Ed. London: SAGE Publications Ltd.

[64] B. C. Stahl 2011, “What Does The Future Hold? A Critical View of Emerging Information and Communication Technologies and Their Social Consequences," in IFIP WG 8.2Working Conference, Turku, Finland, pp. 59-76.

[65] Dit. TTKI 2015, “Tata Kelola Teknologi Informasi dan Komunikasi Di Direktorat Jenderal Pajak,” Presented at The Sosialisasi Tata Kelola TIK DJP, Pusdiklat Pajak.

[66] I. Djuniardi 2018, “Journey to Big Data,” Pusintek Kementerian Keuangan.

[67] G. Booch, J. Rumbaugh, and I. Jacobson 1998, Unified Modeling Language User Guide. Reading, Massachusetts: Addison Wesley. 
[68] DJP 2011, "Surat Edaran Nomor: SE-54 PJ/2011 Tentang Pedoman Pengembangan Aplikasi dan Infrastruktur TIK."

[69] D. Regan, G. Krasadakis, J. Baxter, and Y. Yazicioglu 2017, "The New Data Reality for Revenue Agencies," Accenture.

[70] AICPA 2013, “An Overview of Data Management," ACIPA - IMTA EC - Data Management Task Force,

[71] DAMA International 2017, DAMA-DMBOK: Data Management Body of Knowledge (2nd Edition), Technics Publications. 